\title{
Screening MRI-based prediction model for therapeutic response of MR-HIFU ablation of uterine fibroids
}

\author{
Young-sun Kim", Bilgin Keserci ${ }^{2}$, Hyo Keun Lim', Hyunchul Rhim ${ }^{1}$
}

From Current and Future Applications of Focused Ultrasound 2014. 4th International Symposium

Washington, D.C, USA. 12-16 October 2014

\section{Background/introduction}

With regards to MR-HIFU ablation of uterine fibroids, there have been no screening MR criteria that comprehensively consider multiple influencing factors. The aims of this study was to generate screening MRI-based prediction model for therapeutic responses of MR-guided high-intensity focused ultrasound (MR-HIFU) ablation of uterine fibroids comprehensively considering multiple influencing factors.

\section{Methods}

A total of 160 symptomatic uterine fibroids (diameter $8.3 \mathrm{~cm}$, range $3.1-15.0 \mathrm{~cm}$ ) in 112 women (age 43.3 , range 25-55) who were treated with MR-HIFU ablation were retrospectively analyzed. The following three parameters of screening MRI were evaluated. 1) Subcutaneous fat was measured as a thickness of the most compressed point $(\mathrm{mm})$ on prone position. 2) Relative peak enhancement (\%) was calculated based on time-signal intensity curve analysis of fibroid in perfusion MRI (100 dynamics, 3 s time resolution), in which $0 \%$ refers the same signal intensity as in precontrast image. 3) Signal intensity was assessed as a ratio of $\mathrm{T} 2$ signal intensity of uterine fibroids to that of skeletal muscle. Those parameters were used to generate prediction models with regards to ablation efficiency (i.e., non-perfused volume/ treatment cell volume) and ablation quality (grade 1 5, from poor to excellent), respectively, using generalized estimating equation (GEE) analysis. Then, cut-off values for successful treatment (ablation efficiency $>1.0$; ablation

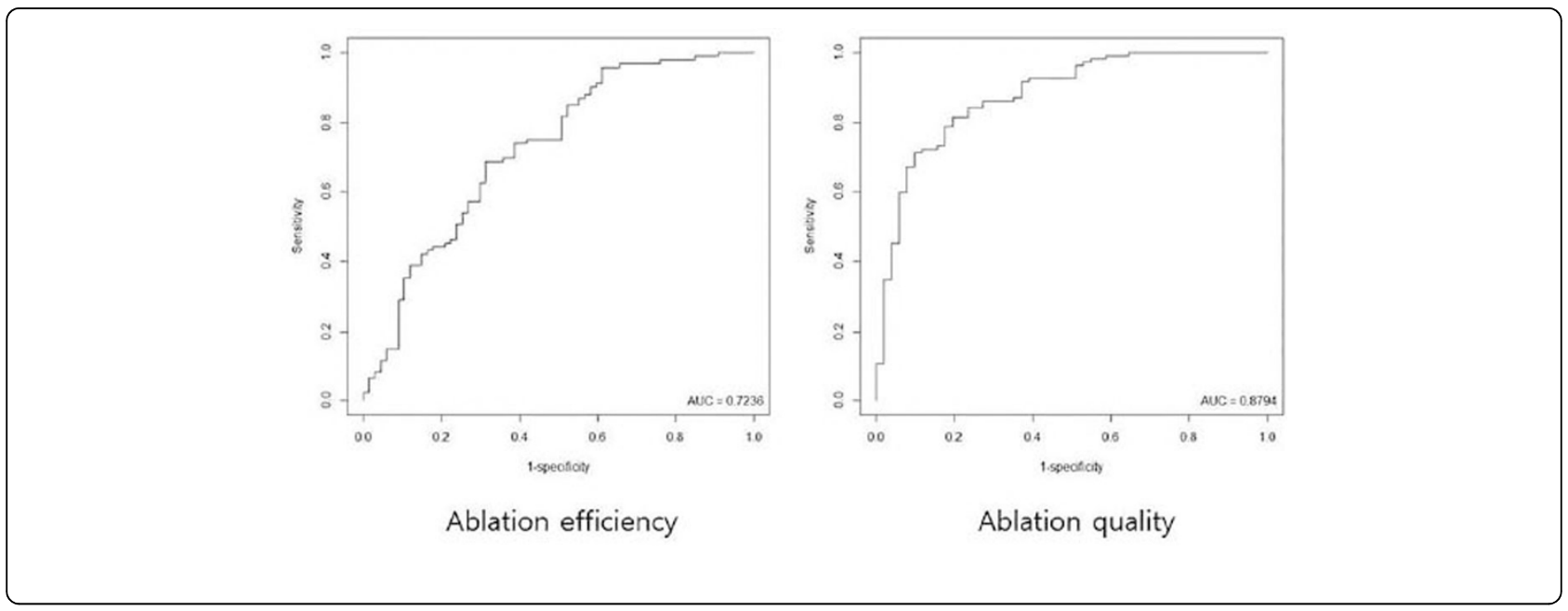

'Samsung Medical Center, Seoul, Republic of Korea

Full list of author information is available at the end of the article

(c) 2015 Kim et al; licensee BioMed Central Ltd. This is an Open Access article distributed under the terms of the Creative Commons 
quality grade 4 or 5) were determined based on receiver operating characteristic (ROC) curve analyses.

\section{Results and conclusions}

GEE analyses produced the models of " $y 1=2.2637-$ $0.0415 \times 1-0.0011 \times 2-0.0772 \times 3$ " and " $\mathrm{y} 2=6.8148-0.1070 \times 1-$ $0.0050 \times 2-0.2163 \times 3$ ", where $y 1=$ ablation efficiency, $\mathrm{y} 2=$ ablation quality, $\mathrm{x} 1=$ subcutaneous fat thickness, $\mathrm{x} 2=$ relative peak enhancement, and $\mathrm{x} 3=\mathrm{T} 2$ signal intensity ratio ( $\mathrm{p}$-values for $\mathrm{x} 1,0.0068$ and $<0.0001$; for $\mathrm{x} 2,0.1952$ and 0.0001; for $\mathrm{x} 3,<0.0001$ and $<0.0001$, respectively). Cut-off values for successful treatments based on ROC curve analyses turned out to be 1.312 for of ablation efficiency (AUC, .7236; sensitivity, .6882; specificity, .6866) and 4.019 for ablation quality (AUC, .8794; sensitivity, .7156; specificity, .9020).

Conclusion: Simple equation models to predict therapeutic responses of MR-HIFU ablation of uterine fibroids in terms of ablation efficiency and quality were generated, which are easily applicable to screening MRI.

\section{Authors' details}

${ }^{1}$ Samsung Medical Center, Seoul, Republic of Korea. ${ }^{2}$ Philips Healthcare, Seoul, Republic of Korea.

Published: 30 June 2015

doi:10.1186/2050-5736-3-S1-098

Cite this article as: Kim et al: Screening MRI-based prediction model for therapeutic response of MR-HIFU ablation of uterine fibroids. Journal of Therapeutic Ultrasound 2015 3(Suppl 1):098.
Submit your next manuscript to BioMed Central and take full advantage of:

- Convenient online submission

- Thorough peer review

- No space constraints or color figure charges

- Immediate publication on acceptance

- Inclusion in PubMed, CAS, Scopus and Google Scholar

- Research which is freely available for redistribution

Submit your manuscript at www.biomedcentral.com/submit
C Biomed Central 